\title{
A Validation of the Multidimensional Perceived Value in the Model of E-loyalty towards Sino-Thai Cross-border E-commerce based on China's Customers
}

\author{
Li Wang iD a Manoch Prompanyo (iD) b \\ a Ph.D. Candidate, Management School of Management, Shinawatra University, nanmu2005@qq.com \\ b Ph.D., Management School of Management, Shinawatra University, manoch.p@siu.ac.th
}

\begin{tabular}{|c|c|}
\hline ARTICLE INFO & ABSTRACT \\
\hline Keywords: & \multirow{5}{*}{$\begin{array}{l}\text { Purpose - The primary purposes of the research are to confirm the stability of multiscale } \\
\text { measurement of perceived value in the E-loyalty model and illustrate the interrelationship between } \\
\text { perceived value, (functional value, procedural value, social value, and emotional value) e- } \\
\text { satisfaction and e-loyalty objectively and comprehensively in the context of Sino-Thai Cross-border } \\
\text { E-commerce (CBE) by the literature analysis and the empirical research. }\end{array}$} \\
\hline Cross-border & \\
\hline E-commerce, & \\
\hline Perceived Value & \\
\hline E-satisfaction & \\
\hline E-loyalty & $\begin{array}{l}\text { Design/Methodology/Approach - This quantitative research collected } 244 \text { valid samples from } \\
\text { online stores via the internet based multichannel approach. The confirmatory factor analysis (CFA) }\end{array}$ \\
\hline Received 17 March 2020 & $\begin{array}{l}\text { and the structural equation modeling (SEM) with Bootstrap were conducted to assess the research } \\
\text { hypotheses. }\end{array}$ \\
\hline Revised 21 April 2020 & \multirow{2}{*}{$\begin{array}{l}\text { Findings - The findings presented that the multidimensional scale of perceived value was capable } \\
\text { of describing and explaining the effects of perceived value on the E-loyalty model. The overall } \\
\text { perceived value positively and indirectly influenced E-loyalty through the mediator of e-satisfaction } \\
\text { in this research. }\end{array}$} \\
\hline il 2020 & \\
\hline Article Classification: & \multirow{2}{*}{$\begin{array}{l}\text { Discussion - The research contributed to the fulfillment of the literature gap in Cross-border E- } \\
\text { commerce. Therefore, if any application and extension of this model to other contexts should be re- } \\
\text { examined. Furthermore, it was also recommended to conduct qualitative analysis to explore and } \\
\text { identify more constructs to rich the concept of Perceived Value in future research. }\end{array}$} \\
\hline Research Article & \\
\hline
\end{tabular}

\section{Introduction}

Evidently, with the extensive use of the Internet and advanced technologies, the upstart of E-commerce namely Cross Border E-commerce (CBE), becomes an especially critical part of the world economy because of its flexibility and convenience. This new international business approach not only lowers the threshold to enter global markets, and assists more merchants in reaching international consumers, but also further enhances the global competition. The key to survive and win this customer-focused marketing battle is building customer loyalty to maintain customers (Reichheld and Schefter, 2000).

Most scholars believe and support that a high degree of perceived value is able to reduce the perceived risk towards online products and generate and improve online customers' loyalty (Liu and Zhang, 2016). However, CBE, especially Sino-Thai CBE as a niche market, only few studies have explored and analyzed their associations within its unique cultural context. Furthermore, in the present researches, most of them still focused on utilizing the unidimensional scale of perceived value to explain their relationship underlying the complex scenario of E-commerce. Thus, lack of proper measurement scale of perceived value is the dominant reason why it is difficult to understand customers' online shopping behavior and eventually establish loyalty. Therefore, this study attempts to redesign the measurement scale of perceived value and validate it in the eloyalty model of Sino-Thai Cross-border E-commerce and investigate its association with e-loyalty in a more comprehensive and realistic way. The final findings are able to make efforts on the fulfillment of the literature gap in this field.

\section{Önerilen Atıf/Suggested Citation}

Wang, L., Prompanyo, M. (2020). A Validation of the Multidimensional Perceived Value in the Model of E-loyalty towards Sino-Thai Cross-border E-commerce based on China's Customers, Journal of Business Research-Turk, 12 (2), 1014-1022. 


\section{Literature Review}

\subsection{Perceived Value}

In academia, perceived value still has contained a massive divergence of the definition and the dimensions of the construct because of its highly situational and context-dependent features. The varied research views of the measurement of perceived value can be classified into two main streams, which are unidimensional construct and multi-dimensional construct (Fernández and Bonillo, 2007). As the unidimensional approach, the most widely recognized definition within this approach is the perceived overall evaluation of product utility (Zeithaml,1988). According to the unidimensional approach, the perceived value is measured simply by rating the value that customers received in making their purchases (Aulia et al., 2016). However, the unidimensional conception of customer perceived value is a more focused and straight forward narrow approach that is not capable to explore and analyze the perceived value, which is depicted as the complicate construct by most scholars (Lapierre, 2000). As recommended by Sweeney and Soutar (2001), "a more sophisticated measure is needed to understand how consumers value products and services." Thus, a more integrated approach multidimensional conception of perceived value involving a lager and broader measurement scale was generated and gained more support from scholars. It embedded perceived price, quality, benefits, and sacrifice (e.g., Sweeney \& Soutar, 2001). In light of this, in this paper defined Perceived Value as "Product value to a consumer is a comparison of tangible and intangible benefits from the generic as well as the supplementary levels of a product and the total costs of production and usage of a product" (Nilson, 1992). With the development of research on Perceived Value, the multidimensional measurement has gradually replaced the unidimensional measurement. Sheth et al. (1991) suggested utilizing 5 dimensions embodying social, emotional, functional, epistemic, and conditional dimensions on measuring the perceived value. After that, Sweeney \& Soutar (2001) recommended removing the epistemic and conditional dimensions form the 5-dimensional measurement due to their temporality. After that, the 3-dimensional approach assisted scholars in illustrating and attesting perceived value in most common scenarios. In those prior studies, Functional value (FV) is conceptualized as "the perceived utility acquired from an alternative's capacity for functional, utilitarian or physical performance" (Sheth et al., 1991); Social value (SV) is "the acceptability at the level of the individuals' relationship with his social environment" (Sheth et al., 1991); Emotional value (EV) is referred to "the perceived utility acquired from an alternative's capacity to arouse feelings or affective states" (Sheth et al., 1991). Unfortunately, this advanced approach was still rarely applied in the study of CBE.

Additionally, given the unique features of CBE, the conventional 3-dimensional approach is not able to help people fully understand perceived value comprehensively. Numerous scholars stressed that underlying the context of online shopping, online customers took more concern on procedural value (PV) involving convenience, website design, and security (e.g., Kassim and Abdullah, 2008) rather than the traditional shopping style. In light of this, this paper extends the traditional measurement to a more robust and legible 4dimensional measurement containing the $\mathrm{FV}, \mathrm{EV}, \mathrm{SV}$, and $\mathrm{PV}$ to evaluate the perceived value and its impacts on the e-loyalty model in the context of Sino-Thai CBE.

\subsection{E-satisfaction}

In this study, E-satisfaction is referred to " the contentment of a consumer concerning his or her prior purchasing experiences with a given retail-oriented website" (Anderson \& Srinivasan, 2003). It is an essential element to evaluate customers' attitudes and behaviors towards products or services in e-commerce. Since the previous study indicates that customers with high satisfaction are less likely price sensitive, more willing to repurchase the products or services, and less influenced by the competitors (Zineldin, 2000).

Besides those benefits, the critical importance is that satisfaction is the antecedent to generate and enhance customer loyalty, which is the primary strategic approach to compete with competitors. There is an extensive range of researches concentrating on the concept of customer satisfaction and its relationship with perceived value and loyalty.

According to the previous literature, it reveals that a large number of studies have confirmed the close association between perceived value and customer satisfaction, which is of great guiding significance to the understanding of customer purchasing behavior (e.g., Nguyen et al., 2018). Most studies have pointed out that perceived value was an essential antecedent for customer satisfaction (e.g., Nguyen et al., 2018). They 
emphasized and manifested that customer satisfaction was the reflection of the perceived value for goods or services in the shopping process. Besides this, their positive correlation has been attested by numerous studies as well (e.g., Hsu et al., 2009). Most of those studies prove that satisfaction is strongly positively related to loyalty. Meanwhile, customer satisfaction also acts as the mediator variable in the relationship between perceived value and loyalty that is supported by many scholars. (e.g., Liu \& Zhang, 2016).

\subsection{E-loyalty}

E-loyalty derived from traditional loyalty involves both the elements of the conventional concept and ecommerce. Thus, Rolph and Srini (2003) conceptualized e-loyalty as "the customer's favorable attitude toward an electronic business resulting in repeat buying behavior." Customer loyalty is a key reason for the enterprises surviving from the fierce competition (Pritchard \& Howard, 1997). The most significant features of loyal online consumers are less price-sensitive (Jaiswal \& Niraj, 2011; Reichheld \& Sasser, 1990) and more repurchasing products and services (Jaiswal \& Niraj, 2011; Pooler, 2003) and making business referrals (Reichheld \& Sasser, 1990; Zeithaml et al., 1996), that is deemed as the most effective marketing strategy to survive this international fierce battle (Pooler, 2003). However, the literature review of measurements of eloyalty has pointed out that extensive scholars attempted to investigate and analyze it in different ways, but they still failed to standardize an instrument to measure it (Valvi and Fragkos, 2012). The most common factors that have been selected and approved by scholars were customer satisfaction and perceived value (Valvi and Fragkos, 2012).

The positive association between e-satisfaction and e-loyalty has been examined by numerous research (e.g., Hsu et al., 2009). Most of those studies proved that satisfaction was strongly positively related to loyalty. This finding has been proved continuously over various countries and purchase size. Based on the previous literature, the notion of e-loyalty has been extensively manifested by the antecedents such as perceived value, and customer satisfaction, which was strong evidence to prove they as the primary antecedent influences on e-loyalty (e.g., Liu and Zhang, 2016).

\subsection{The conceptual model and hypotheses}

After reviewing 45 papers of customer loyalty, more than 30 articles determine and prove that perceived value, customer satisfaction, and customer loyalty have a significant interrelationship under various industries, different countries, and conditions. In literature, most scholars confirmed and validated E-satisfaction had a significant mediation effect on the relationship between Perceived Value and E-loyalty. The most recognized model to prove those associations was the ACSI (the American Customer Satisfaction Index) model, which was widely employed in over 10 economic sectors and 46 critical industries (The Science of Customer Satisfaction, n.d.).

With the further development of research on perceived value, multidimensional measurement has been employed in the loyalty model. Based on the literature analysis, this paper utilized the 4-dimensional approach to measure the perceived value in the e-loyalty model towards Sino-Thai Cross-border E-commerce and attempted to offer a more comprehensive and realistic analysis. Therefore, the following hypotheses are proposed:

$\mathrm{H}_{1}$ The scale of 4-dimensional measurement of perceived value is stable in the context of Sino-Thai CBE.

$\mathbf{H}_{2}$ Perception Value positively impacts on E-satisfaction.

$\mathrm{H}_{3}$ E-satisfaction positively impacts on E-loyalty.

$\mathbf{H}_{4}$ Perception Value positively impacts on E-loyalty.

$\mathrm{H}_{5}$ E-satisfaction has a mediation effect on the relationship between Perceived Value and E-loyalty.

\section{Methodology and Data Analysis}

\subsection{Research Instrument and Pilot Test}

This research adopted survey questionnaires as the principal tool to collect and explain data, and manifest proposed Hypotheses. A multiple-item scale questionnaire derived from prior studies indicated high statistical reliability and validity to ensure the data reflect the real scenario accurately. The questionnaire was 
composed of 3 parts and covers the demographic inquiries, the online-behavior-related inquiries, and the conceptual-framework-related inquiries (Table 1). The scales for measuring FV, EV, and SV are that of Sweeney \& Soutar (2001). The items belong to procedure value, E-satisfaction and E-loyalty are derived from Carlson et al. (2015). All the scales are measured on a seven-point Likert scale ranging from (1) strongly disagree and (7) strongly agree.

Table1. The Conceptual Framework Related Questionnaires

\begin{tabular}{|c|c|c|c|}
\hline \multicolumn{2}{|r|}{ Variables } & Items & References \\
\hline \multirow{14}{*}{ 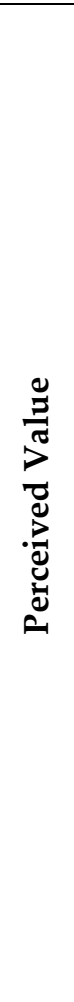 } & \multirow{4}{*}{ FV } & The product of Sino-Thai CBE is reasonably priced. & \multirow{4}{*}{$\begin{array}{l}\text { Sweeney \& } \\
\text { Soutar (2001); }\end{array}$} \\
\hline & & The product of Sino-Thai CBE offers value for money. & \\
\hline & & The product of Sino-Thai CBE has consistent quality. & \\
\hline & & The quality of services of Sino-Thai CBE has been offered. & \\
\hline & \multirow{4}{*}{ PV } & The Sino-Thai CBE website's appearance is professional. & \multirow{4}{*}{$\begin{array}{c}\text { Carlson et al. } \\
\text { (2015) }\end{array}$} \\
\hline & & $\begin{array}{l}\text { It is quick and easy to complete a transaction at the Sino-Thai } \\
\text { CBE website. }\end{array}$ & \\
\hline & & $\begin{array}{l}\text { I feel that my privacy is protected at the Sino-Thai CBE } \\
\text { website. }\end{array}$ & \\
\hline & & I feel safe in my transactions with the Sino-Thai CBE website. & \\
\hline & \multirow{3}{*}{ EV } & The product of Sino-Thai CBE is one that I would enjoy. & \multirow{3}{*}{$\begin{array}{c}\text { Sweeney \& } \\
\text { Soutar (2001); }\end{array}$} \\
\hline & & The product of Sino-Thai CBE would make me want to use it. & \\
\hline & & $\begin{array}{l}\text { The product of Sino-Thai CBE is one that I would feel relaxed } \\
\text { about using. }\end{array}$ & \\
\hline & \multirow{3}{*}{ SV } & $\begin{array}{l}\text { The product of Sino-Thai CBE would give its owner social } \\
\text { approval. }\end{array}$ & \multirow{3}{*}{$\begin{array}{l}\text { Sweeney \& } \\
\text { Soutar (2001); }\end{array}$} \\
\hline & & $\begin{array}{l}\text { The product of Sino-Thai CBE would help me to feel } \\
\text { acceptable. }\end{array}$ & \\
\hline & & $\begin{array}{l}\text { The product of Sino-Thai CBE would make a good impression } \\
\text { on other people. }\end{array}$ & \\
\hline \multirow{3}{*}{\multicolumn{2}{|c|}{ E-satisfaction }} & $\begin{array}{l}\text { I'm satisfied with my decision to buy the product and service } \\
\text { of Sino-Thai CBE. }\end{array}$ & \multirow{3}{*}{$\begin{array}{l}\text { Carlson et al. } \\
\text { (2015); }\end{array}$} \\
\hline & & It is a wise choice to buy from the website of Sino-Thai CBE. & \\
\hline & & I am satisfied with the Websites of Sino-Thai CBE. & \\
\hline \multirow{3}{*}{\multicolumn{2}{|c|}{ E-loyalty }} & $\begin{array}{l}\text { I would recommend this product of Sino-Thai CBE to friends } \\
\text { or relatives. }\end{array}$ & \multirow{3}{*}{$\begin{array}{l}\text { Carlson et al., } \\
\text { (2015); }\end{array}$} \\
\hline & & $\begin{array}{l}\text { In the future, I will continue to purchase the product of Sino- } \\
\text { Thai CBE. }\end{array}$ & \\
\hline & & $\begin{array}{l}\text { I will make E-shopping as my first choice if I need to buy a } \\
\text { product. }\end{array}$ & \\
\hline
\end{tabular}

Before finalizing the questionnaire, the professors and experts from both Chinese and Thai universities assisted in revising either the format or the wording of the English and Chinese inquiries, removing or correcting any misunderstandings or ambiguities of expression. Then 30 online customers were selected for the Pilot-Test and Cronbach's $\alpha$ coefficient test revealed that all the values surpassed the threshold 0.7, presenting a high level of reliability (Nunnally, 1978). Then, the self-administrated online questionnaire was utilized as the first approach to collect primary data.

\subsection{Sample Collection}

The target customers of this research were those online customers who had shopping experience in the platforms of the Sino-Thai CBE aged from 18 to 44.300 online survey linkages were distributed to the target interviewees through multi-channel like WeChat. Finally, 253 surveys had been retrieved, among which 9 incomplete and invalid questionnaires had been removed. Hence, the response rate was $84.3 \%$, and the sample 
size 244 exceeded the minimum required size 200 suggested by Nunnally (1978), which was feasible for further data analysis.

\subsection{Demographic Factor Analysis}

Demographically, $78.3 \%$ of the respondents were females; $43 \%$ were aged between 25 and 34, and the following group was 35-44 (34.1\%); 39\% held a bachelor's degrees, and 29.1\% held a master's degree and above; $79 \%$ were employees; $67 \%$ had more than $¥ 8,001$ monthly income. Approximately, $90.1 \%$ of the respondents used the Internet 1-6 hours per day and 61.7\% at least shopping 3 times in the websites of SinoThai Cross-Border E-commerce. Thus, the profile of those target customers who were 18-44 working females, with high educational background and monthly income, usually spending 1-6 hours on surfing websites per day and purchasing products from the platforms of Sino-Thai Cross Border E-commerce at least 3 times per year.

\subsection{Confirmatory Factor Analysis (CFA): Reliability and Validity Test}

Table 2. The Result of the CFA Analysis

\begin{tabular}{|c|c|c|c|c|c|c|c|c|c|}
\hline \multirow{2}{*}{ Construct } & \multirow{2}{*}{ Item } & \multicolumn{3}{|c|}{ Parameter Significance Estimation } & \multicolumn{2}{|l|}{ FL } & \multicolumn{2}{|l|}{ IL } & \multirow{2}{*}{$\frac{\text { CV }}{\text { AVE }}$} \\
\hline & & Unstd. & S.E. & t-value & $\mathbf{P}$ & Std. & SMC & $\mathrm{CR}$ & \\
\hline \multirow{4}{*}{ FV } & FV1 & 1.000 & & & & .797 & .635 & .903 & .701 \\
\hline & FV3 & 1.090 & .075 & 14.512 & $* * *$ & .846 & .716 & & \\
\hline & FV2 & 1.046 & .073 & 14.363 & *** & .839 & .704 & & \\
\hline & FV4 & 1.011 & .068 & 14.912 & $* * *$ & .865 & .748 & & \\
\hline \multirow{4}{*}{ PDV } & PDV1 & 1.000 & & & & .787 & 619 & .903 & 699 \\
\hline & PDV2 & 1.037 & .075 & 13.873 & $* * *$ & .825 & .681 & & \\
\hline & PDV3 & 1.072 & .074 & 14.399 & *** & .851 & .724 & & \\
\hline & PDV4 & 1.014 & .068 & 14.897 & $* * *$ & .878 & .771 & & \\
\hline \multirow{3}{*}{ EV } & EV1 & 1.000 & & & & .891 & .794 & .890 & .730 \\
\hline & EV2 & .951 & .060 & 15.829 & $* * *$ & .845 & .714 & & \\
\hline & EV3 & .990 & .064 & 15.427 & $* * *$ & .825 & .681 & & \\
\hline \multirow{3}{*}{ SV } & SV1 & 1.000 & & & & .898 & .806 & .933 & .823 \\
\hline & SV2 & 1.001 & .047 & 21.179 & $* * *$ & .907 & .823 & & \\
\hline & SV3 & 1.039 & .048 & 21.540 & $* * *$ & .916 & .839 & & \\
\hline \multirow{3}{*}{ ES } & ES1 & 1.000 & & & & .860 & .740 & .871 & .692 \\
\hline & ES2 & 1.033 & .074 & 13.934 & $* * *$ & .842 & .709 & & \\
\hline & ES3 & .985 & .074 & 13.293 & $* * *$ & .792 & .627 & & \\
\hline \multirow{3}{*}{ EL } & EL1 & 1.000 & & & & .768 & .590 & .846 & .648 \\
\hline & EL2 & 1.133 & .096 & 11.759 & $* * *$ & .898 & .806 & & \\
\hline & EL3 & .966 & .086 & 11.183 & $* * *$ & .740 & .548 & & \\
\hline
\end{tabular}

Note: FL=Factor Loading; IR=Item Reliability; CR=Composite Reliability; CV= Convergent Validity, AVE= Average Variance Extracted, ${ }^{* * *}<=.001$

The inspection of reliability and validity for this research was primarily focused on the examination of construct reliability and validity by using a confirmatory factor analysis (CFA). This research assessed the item reliability, composite reliability, convergent validity, and discriminant validity of the scale via standard factor loading and SMC. From the results (Table2), all the factor loadings and SMC of the items surpassed the cuffoff point .7 and .5 respectively that represented the consistency of each item to its construct was pretty good; all the values of CR for each construct exceed the recommended .7 (Fornell and Larcker, 1981); while in terms of convergent validity, the values of AVE ranging from .648 to .823 above the benchmark value .5 (Hair et al., 2014); regarding to discriminant validity, all the diagonal values (Table 3)representing the square root of AVE were above the correlations between each construct and any other constructs that perfectly matched the statistical requirements. Besides this, the overall goodness-of-fit statistics of this multidimensional model 
L. Wang - M. Prompanyo 12/2 (2020) 1014-1022

exhibited that the AGFI (.930) and GFI (.951) values were higher than the desired minimum value 0.9, with $\chi 2 / \mathrm{DF}=1.249$ (ideally 3 or lower), RMSEA $=.003$, and SMAR=.004 (ideally .08 or lower).

Table 3. Convergent Validity and Discriminant Validity

\begin{tabular}{cccccccc}
\hline Construct & AVE & EV & EL & ES & SV & PDV & FV \\
\hline EV & .730 & .854 & & & & & \\
EL & .648 & .204 & .805 & & & \\
ES & .692 & .213 & .782 & .832 & & \\
SV & .823 & .136 & .588 & .718 & .907 & & \\
PDV & .699 & .324 & .572 & .716 & .611 & .836 & .837 \\
FV & .701 & .245 & .489 & .684 & .587 & .672 & \\
\hline
\end{tabular}

Note: Diagonal elements (bold) $=$ the square root of AVE

The 4-dimensional measure of perceived value displayed that all standardized regression weights of dimensions except emotional value reached the threshold level (Figure 1). The results present that there was no difference between the sample covariance matrix and the model covariance matrix, so as to $\mathrm{H}_{1}$ was proved.

\subsection{The Structural Model Analysis}

The structural modeling results represented that the conceptual model had the compatibility of collected data $(\chi 2=167.71, \mathrm{df}=163, \chi 2 / \mathrm{df}=1.029, \mathrm{GFI}=.94, \mathrm{AGFI}=.92, \mathrm{RMSEA}=.01, \mathrm{SMAR}=.04)$. The path coefficients (Figure 1) from PV to ES and from ES to EL were $.89(\mathrm{p}<.01)$ and $.77(\mathrm{p}<.01)$ respectively, indicating PV and ES positively and significantly impacted ES and EL that supported $\mathbf{H}_{2}$ and $\mathbf{H}_{3}$ robustly. However, the research result revealed that PV did not influence EL significantly that rejected the proposed $\mathrm{H}_{4}$. SMC values associating with FV, PDV, $\mathrm{SV}, \mathrm{ES}$, and EL were in the range of .6 and .89 , which were close or above the benchmark point of substantial level .7. It demonstrated the large portion of variances of latent variables could be explained by its antecedents.

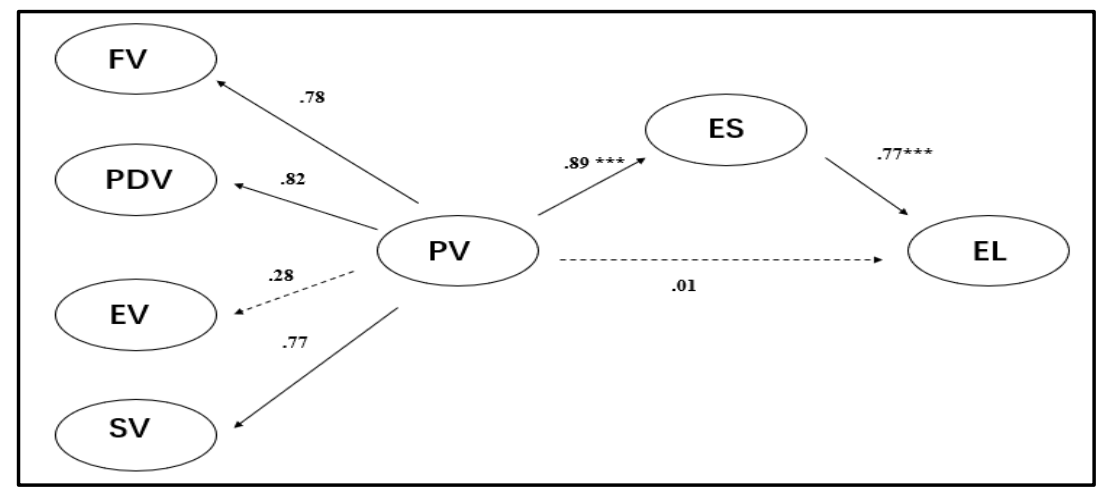

Note: ${ }^{* * *}$ significant at $\mathrm{p}<.001$

Figure1. Structural results of the hypotheses model $(\mathrm{N}=244)$.

To be concluded (Figure 1), relying on empirical study, the result confirmed the $\mathrm{H}_{2}$ and $\mathrm{H}_{3}$, and only $\mathrm{H}_{4}$ was rejected.

\subsection{Mediation Analysis}

This paper adopted bootstrap as the approach to measuring the intervening effect of E-satisfaction to avoid the statistical errors from non-normally distributed sampling in the empirical study (Bollen and Stine, 1990; 
Stone and Sobel, 1990; Mackinnon et al., 2004;). According to the suggestions from previous scholars (Taylor, et al., 2008), 5000 samples with 95\% confidence interval was conducted in this research.

As shown in Table 4, bias-corrected $95 \%$ CI of the total effect and indirect effect from PV to EL did not include 0 that demonstrated there were significant mediation effects on those paths through ES. However, the biascorrected 95\% CI of the direct effect included 0. In other words, all the factors of PV and SV did not have significant direct associations with EL. This result indicated ES fully mediated the relationship between PV and EL that supported $\mathrm{H}_{5}$.

Table 4. The analysis mediation effect

\begin{tabular}{|c|c|c|c|c|c|c|}
\hline \multirow{3}{*}{ SIE } & \multirow{3}{*}{$\begin{array}{c}\text { Point } \\
\text { Estimation }\end{array}$} & \multirow{2}{*}{\multicolumn{2}{|c|}{ Product of Coef. }} & \multicolumn{3}{|c|}{ Bootstrapping } \\
\hline & & & & \multicolumn{3}{|c|}{ Bias-corrected 95\% CI } \\
\hline & & $\overline{S E}$ & $\bar{Z}$ & Lower & Upper & $\mathbf{P}$ \\
\hline PVtoEStoEL & .921 & 1.276 & .722 & .115 & 5.198 & .043 \\
\hline PVtoEL & .011 & 1.265 & .009 & -1.020 & 2.493 & .893 \\
\hline totalPV & .932 & .262 & 3.557 & .491 & 1.479 & .001 \\
\hline
\end{tabular}

Note: 5000 bootstrap sample; IE=Indirect Effect; DE=Direct Effect.

\section{Conclusion and Implication}

This research manifested the applicability of the measurement scale of Perceived Value in the E-loyalty model to the Sino-Thai Cross-border E-commerce while simultaneously emphasized specificities of the Sino-Thai Cross-border E-commerce. Against the above result, the conclusions and implication suggestions can be drawn in the below:

First of all, in the context of the Sino-Thai CBE, although EV did not appear contributing to PV significantly, 4-dimensional measurement of Perceived Value was still stable to measure E-loyalty. Further, the findings reconfirmed the factors of perceived value impacting e-loyalty were highly context-dependent and varied the degree of their impacts in various situations. In reference to the results of this research, it suggested the firms of the Sino-Thai Cross-border E-commerce to reallocate their resources and make great efforts to improve functional value, procedural value, and social to generate a high standard of overall perceived value and then enhance customers' e-loyalty ultimately.

Moreover, the result of this research illustrated the 3 factors of perceived value impact on E-loyalty in different weights. Procedural value had a profound contribution to the overall perceived value, the next was functional value. The findings presented the customers concerning the social identity, products' utilities, and procedural benefits rather than feeling or affection aroused from the products or services in the Sino-Thai Cross-border E-commerce. This result was consistent with the character description of the report, which indicated those customers were mature and rational, task-oriented, and clarifying what kinds of products they needed (China's Cross Border E-commerce Report, 2019). The findings recommend that under the limited resources when the entrepreneurs further strengthen and enlarge the effects from perceived value towards customer loyalty, they should concern those three factors by their impact weights towards perceived value and procedural value should be put the priority position. It was also a wise decision to generate standards or criteria towards those 3 values to monitor and control them in the right direction. 
Finally, proved H1, H2, H3, and H5 reconfirmed the e-loyalty model derived from the prior research remaining stable underlying the Sino-Thai Cross-border E-commerce. Meanwhile, this result indicated that it was not able to modify the perceived value to influence e-loyalty directly in the context of Sino-Thai CBE. In this sense, to generate or enhance e-loyalty entrepreneurs should not only rely on the fulfillment of perceived value but also pay great attention to the mediator of e-satisfaction of the e-loyalty model.

\section{Limitations and Future Direction}

Firstly, these scales were designed and developed specifically for interpreting the influence of Perceived Value towards E-loyalty in the context of Sino-Thai CBE; therefore, any application and extension to other contexts should be re-examined. Secondly, the scales derived from previous research may not cover all the dimensions belonging to Perceived Value. Future research could adopt qualitative analysis to explore and identify more constructs to fulfil the concept of Perceived Value.

\section{References}

Anderson, R. E., \& Srinivasan, S. S. (2003). E-satisfaction and e-loyalty: a contingency framework. Psychology and Marketing, 20(2), 123-138.

Aulia, B., Utama, W., and Ariastita, P. (2016). "Location Analysis for Petrol Filling Station Based on Stakeholders' Preference and Seismic Microzonation", Procedia - Social and Behavioral Sciences, 227, 115-123.

Bollen, K. A., and Stine, R. (1990). "Direct and indirect effects: Classical and bootstrap estimates of variability", Sociological Methodology, 20, 115-140.

Carlson, J., O'Cass, A., and Ahrholdt, D. (2015). "Assessing customers' perceived value of the online channel of multichannel retailers: A two country examination", Journal of Retailing and Consumer Services 27 (2015), 90-102.

China's Cross Border E-commerce Report. (2019), 100ec, available at: http://www.100ec.cn/detail-6512462.html (accessed 21 March, 2019).

Fernández, R., and Bonillo, M. (2007). "The concept of perceived value: A systematic review of the research", Mark Theory, 7, 427-451.

Fornell, C., and Larcker, D. F. (1981). “Evaluating structural equation models with unobservable variables and measurement error", Journal of Marketing Research, 18(1), 39-50.

Fornell, C., \& Birger, W. (1987). Defensive Marketing Strategy by Customer Complaint Management, Journal of Marketing Research, 24 (11), 37-46.

Hair, J. F., Hult, G. T. M., Ringle, C. M., and Sarstedt, M. (2014). A Primer on Partial Least Squares Structural Equation Modeling (PLS-SEM), Sage, Thousand Oaks.

Hsu, C. I., Lin, B. Y., and Chang, K. C. (2009). “On-line Shopping Loyalty and Its Antecedents”, International Journal of Information, 5(1), 11-20.

Jaiswal, A.K., \& Niraj, R. (2011). Examining Mediating Role of Attitudinal Loyalty and Nonlinear Effects in Satisfaction - Behavioral Intentions Relationships. Journal of Services Marketing, 25(3), 165-175.

Kassim, N., and Abdullah, N. (2008). "Customer Loyalty in e-Commerce Settings: An Empirical Study", Electronic Markets,18, 275-290.

Lapierre, J. (2000). "Customer-perceived value in industrial contexts", Journal of Business \& Industrial Marketing, 15(2/3), 122-145.

Liu, L., and Zhang, N. (2016). "Research on the Relationship between Customer Perceived Value, Satisfaction and Loyalty- Empricial Analysis based on the Electronic Commerce Market", Journal of Information Resources Management, 3, 50-57. 
L. Wang - M. Prompanyo 12/2 (2020) 1014-1022

MacKinnon, D. P., Lockwood, C. M., and Williams, J. (2004). “Confidence limits for the indirect effect: Distribution of the product and resampling methods", Multivariate Behavioral Research, 39, 99-128.

Nguyen, H.T., Nguyen, H., Nguyen, N.D., and Phan, A.C. (2018). “Determinants of Customer Satisfaction and Loyalty in Vietnamese Life-Insurance Setting", Sustainability, 10 (4), 1151-1165.

Nilson, T.H. (1992). Value-added Marketing, London, McGraw-Hill.

Nunnally, J. C. (1978). Psychometric theory (2nd ed.), New York, McGraw-Hill.

Pooler, J. (2003). Why We Shop: Emotional Rewards and Retail Strategies. Westport, CT: Praeger.

Pritchard, M. P., \& Howard, D. R. (1997). The Loyal Traveler: Examining a Typology of Service Patronage. Journal of Travel Research, 35(Spring), 2-10.

Reichheld, F. F. (1996), The Loyalty Effect. Boston, MA: Harvard Business School Press.

Reichheld, F. F., \& Earl, S. W. (1990), Zero Defections: Quality Comes to Services, Harvard Business Review, 68 (September/October), 105-11.

Reichheld, F. F., and Schefter, P. (2000). “E-loyalty:Your secret weapon on the Web”, Harvard Business Review, $78,105-113$

Rolph E. A., and Srini S. S, (2003). “E-Satisfaction and E-Loyalty: A Contingency Framework. Psychology \& Marketing", 20(2), 123-138.

Valvi, A., and Fragkos, K. (2012). "Critical review of the e-loyalty literature: A purchase-centred framework", Electronic Commerce Research, 12 (3), 331-378.

Sheth, J., Newman, B., and Gross, B. (1991). "Why We Buy What We Buy: A Theory of Consumption Values", Journal of Business Research, 22, 159-170.

Stone, C. A., and Sobel, M. E. (1990). "The robustness of total indirect effects in covariance structure models estimated with maximum likelihood", Psychometrika, 55, 337-352.

Sweeney, J., and Soutar, G. (2001). “Consumer Perceived Value: The Development of a Multiple Item Scale. Journal of Retailing", 77, 203-220.

Taylor, A., MacKinnon, D., and Tein, J-Y. (2008). "Tests of the Three-Path Mediated Effect", Organizational Research Methods, 11. 241-269.

The Science of Customer Satisfaction (n.d.), Theacsi, available at: https://www.theacsi.org/about-acsi/thescience-of-customer-satisfaction (accessed 21 March, 2019).

Zeithaml, V.A. (1988). "Consumer perceptions of price, quality and value: A means-end model and synthesis of evidence", Journal of Marketing, 52(3), 2-22.

Zeithaml, V., Berry, L., \& Parasuraman, A. (1996). The behavioural consequences of service quality. Journal of Marketing, 60(2), 31-46.

Zineldin, M. (2000). Total relationship management (TRM) and total quality management (TQM). Managerial Auditing Journal, 15(1-2), 20-28. 